\title{
2. Pacific Media Watch and protest in Oceania: An investigative free media case study
}

\section{AB SIRACI}

In the past three decades, global and regional media freedom advocacy and activist groups have multiplied as risks to journalists and media workers have escalated. Nowhere has this trend been so marked as in the Oceania region where some four organisations have developed a media freedom role. Of these, one is unique in that while it has had a regional mission for almost two decades, it has been continuously based at four university journalism schools in Australia, Fiji, New Zealand and Papua New Guinea. Pacific Media Watch was founded as an independent, non-profit and nongovernment network by two journalism academics in the Australian Centre for Independent Journalism (ACIJ) at the University of Technology, Sydney. Its genesis was the jailing of two Taimi 'o Tonga journalists, 'Ekalafi Moala and Filokalafi 'Akau'ola, and a 'whistleblowing' pro-democracy member of Parliament in Tonga, 'Akilisi Pohiva, for alleged contempt in September 1996. PMW played a role in the campaign to free the three men. Since then, the agency has developed an investigative journalism strategy to challenge issues of ethics, media freedom, industry ownership, cross-cultural diversity and media plurality. One of PMW's journalists won the 2013 Dart Asia-Pacific Centre for Journalism and Trauma Prize for an investigation into torture and social media in Fiji. This article presents a case study of the PMW project and examines its history and purpose as a catalyst for independent journalists, educator journalists, citizen journalists and critical journalists in a broader trajectory of Pacific protest.

Keywords: citizen journalism, investigative journalism, media censorship, media freedom, media mobilisation, media plurality, political change, public interest

DAVID ROBIE

Pacific Media Centre, Auckland University of Technology 
W HEN the kingdom of Tonga's Parliament convened on 19 September 1996, an event took place that shattered any illusions about press freedom and democracy in the South Pacific. A whistleblower member of Parliament and two journalists were accused of contempt and faced an unprecedented trial in the South Pacific region. As Tongan newspaper publisher and broadcaster 'Ekalafi Moala (2002), one of the accused, described it in his book Island Kingdom Strikes Back:

Nothing like this had ever happened before. A trial of sorts was to be held in the Legislative Assembly. [Samuela 'Akilisi] Pohiva, Filokalafi ['Akau'ola] and I were summoned and charged for the crime of contempt of Parliament, not in a court of justice but in the Assembly's Chamber. (Moala, 2002, p. 149)

The imprisonment of commoner MP Pohiva and the two journalists, Taimi 'o Tonga editor Kalafi Moala and his deputy editor Filokalafi 'Akau'ola, on September 20 for contempt shocked media and human rights circles throughout the Pacific and internationally (see Moala, 2002; Robie, 2006). Pohiva, at the time undoubtedly the best-known whistleblower in the region, had waged a decade-long campaign for open government and democracy in the kingdom, and he had exposed a Tongan passports-for-sale scandal in his newsletter Ko'e Kele'a (www.kelea.to).

Many media commentators saw the jailings in Tonga as the most serious threat to media freedom in the South Pacific since the Fiji coups in 1987. Although news media in neighbouring Australia and New Zealand largely ignored the jailings, in spite of a parallel with five Australian journalists having faced imprisonment or fines in contempt of court cases, several organisations treated the issue seriously (Ingham, 2007; Pearson, 2013) - including the Australian Centre for Independent Journalism (ACIJ), which established a daily 'Tongan jailings update' on its Online Journalist website (acij.uts.edu.au).

One of the jailed men, 'Akau'ola, had earlier been detained for 24 hours in February 1996 after his newspaper published a letter criticising Police Minister Clive Edwards. However, journalists at the ACIJ of the University of Technology, Sydney, launched a campaign in support of the so-called 'Tongan three'. A fledgling media freedom monitoring group, Pacific Media Watch, was set up by two colleagues, the author, then head of the University of Papua New Guinea journalism programme and who was also studying and teaching 
on sabbatical at UTS, and investigative journalist Peter Cronau, then editor of the centre's media magazine, Reportage, who was subsequently an awardwinning investigative journalist on $\mathrm{ABC}$ Four Corners. A voluntary group with no funding, Pacific Media Watch established a media freedom news service and launched an international letter campaign calling for the three prisoners to be released. More than 170 protest letters from academics, journalists, media commentators and students were sent to the kingdom. Moala recalled later in his book about the PMW 'source of comfort':

Beneath the Pacific Media Watch headline of 'Protests mount over Tongan journalist jailing' ... [David] Robie and Peter Cronau wrote: 'We protest over the campaign of media harassment and suppression of freedom of expression by the Tongan government which has led to the detention of journalists and politicians for the third time in less than a year. (Moala, 2002, p. 243)

The three men walked free on October 14 after having served just three weeks of their 30-day sentence following the Tongan Supreme Court ruling that they had been detained illegally in violation of the Constitution. According to New Zealand civil rights lawyer Barry Wilson, acting on their behalf for the Commonwealth Press Union, their release was encouraging for emerging democratic freedoms in the kingdom: 'The court found that the three had not been covered by the normal safeguards for a trial provided under the Constitution. Therefore the court came to the conclusion that they were being illegally detained' (Robie, 1996, p. 11). Wilson successfully filed a writ of habeas corpus after two earlier attempts had failed.

The Tongan jailings was the genesis of Pacific Media Watch, which later became a regional independent Pacific media freedom monitor based at the University of Papua New Guinea (1996-98), University of the South Pacific (1998-2002), AUT University (2002-2007), and finally being adopted as the Pacific Media Watch Freedom Project at AUT's new Pacific Media Centre (PMC) (2007 onwards) (see Pacific Media Watch Project, 2007) when postgraduate interns began working for PMW. While initially a voluntary group involving journalists, academics, media analysts and students with the initial website hosted on Pactok, a Sydney-based web project of the Association of Progressive Communications (APC), Pacific Media Watch gained its first development grant in 2007 when adopted by the PMC. It was subsequently 
awarded a grant by the Pacific Development and Conservation Trust of New Zealand's Ministry of Foreign Affairs and Trade in 2009 ('Pacific Media Watch expands resources', 2010).

This article explores how Pacific Media Watch has evolved and developed a strategy to challenge issues of ethics, media freedom, industry ownership, cross-cultural diversity and media plurality and how it has been involved in reporting coups d'etat, civil conflict and media independence. This is a case study of the PMW project and examines its history and purpose as a catalyst for journalists, media educators, citizen journalists and critical journalists in a broader trajectory of Pacific protest.

\section{The Pacific Media Watch Project}

Each year, four global media freedom organisations - the Committee to Protect Journalists (CPJ), Reporters sans Frontières (RSF), the International Press Institute (IPI) and Freedom House- produce reports monitoring developments over the previous year (Becker, 2003). The Pacific Media Watch project has evolved in a context of several competing, sometimes complementary, media freedom organisations in the South Pacific. A survey of such groups in 2011 ('Moala warns over "new forces",' 2010; Perrottet, 2011; Perrottet \& Robie, 2011) warned of a 'growing minefield of media abuses', ranging from unofficial clampdowns on freedom of expression in Tonga, to violent attacks on media staff in Vanuatu and official laws silencing criticism of Fiji's military-backed government. Participating groups in Pacific media freedom issues include network leaders from the AIDB Pacific Media Partnership, IFJ Pacific Media Human Rights and Democracy Project, Pacific Alliance for Development Journalists, Pacific Freedom Forum (PFF), Pacific Islands Media Association (PIMA), Pacific Islands News Association (PINA), Pacific WAVE Media Network and PasiMA. The major regional media network, the Suva-based PINA, claims to represent 23 media organisations around the region and has a foundation policy of 'defending freedom of expression and information' (Perrottet, 2011). According to the PMW-compiled survey, the main groups were identified as:

PINA (Pacific Islands News Association): Founded in 1972, this Suva-based organisation has long been regarded as the major media body of the Pacific. While critics argue this is no longer the case, PINA remains the major player in town. Moses Stevens [of Vanuatu], current 
president of PINA, writes for the Vanuatu Times. PINA owns a regional news agency PACNEWS, which came under PINA's control after the 2004 merger of PINA and the now-defunct Pacific Islands Broadcasting Association (PIBA). It is the best-funded of any of the Pacific media groups and donors include [Australian Aid]. PINA has been criticised for 'kowtowing' to the Fiji regime in recent years and high-profile members have since resigned. Publishes: PACNEWS www.pina.com.fj

PFF (Pacific Freedom Forum): This group was founded in 2008 and is registered in the Cook Islands ... The organisation operates a successful online Pacific Islands Journalists Online network (PIJO) and posts regular alerts. It recently came to the defence of Marc Neil-Jones, publisher of the Vanuatu Daily Post, who was brutally attacked in his office [in 2011] — allegedly by government minister Harry Iauko. The PFF is supported by the International Federation of Journalists (IFJ), which launched a European Union-funded Pacific Media Human Rights and Democracy Project in 2010. Publishes: PFF media freedom alerts www.pacificfreedomforum.org

PMW (Pacific Media Watch): Founded in 1996 by a network of independent journalists ... This group is now run by the Pacific Media Centre at AUT University in Auckland. The project is partially funded by a Pacific Development and Conservation Trust grant and holds extensive media, video and document archives, many of them on DSpace or Drupal platform databases. ... PMC is a regional media and publications centre and publishes news, books and [media research]. It is also a base for postgraduate Asia-Pacific media students and runs international media projects with industry partners. Publishes: Pacific Media Watch nius, Pacific Journalism Review, Pacific Journalism Monographs, Pacific Scoop and PMC Online. www.pacmediawatch.aut.ac.nz

PasiMA (Pasifika Media Association): This group is the youngest of the media freedom bodies to rise out of the islands. With notable figures such as president Savea Sano Malifa, editor-in-chief of the Samoa Observer, as well as Kalafi Moala, chief executive of Tonga's Taimi Media Network, PasiMA emerged mainly through members' dissatisfaction with PINA. On its website, PasiMA describes itself as the 'professional association of Pasifika's regional independent media owners, operators and principals'. Publishes: Pasifika News Feed. pacificmedia.org (see Perrottet, 2011) 


\section{INVESTIGATIVE JOURNALISM TRENDS}

When the PMW project was re-established at AUT University in 2007 as a non-profit research, resource and publication project, it was awarded an initial faculty development grant from the Creative Industries Research Industry (CIRI) with the objective of 'researching, monitoring and communicating about the South Pacific media industry, professional practice, freedom of speech and media ethics' (Pacific Media Watch Research Project, 2007). The project document stated:

The purpose of [this] project is not merely ensuring the survival of an existing research resource and documenting historical Pacific media material, it also aims to establish a dynamic sustainable information management system which will in future enable contemporary Pacific media developments to be more comprehensively documented, interrogated and debated. (Ibid.)

In a supporting letter, co-founder Peter Cronau, by then an investigative journalist with the Australian Broadcasting Corporation's Four Corners programme, wrote: 'After 10 years of operation initially from a base at UTS, then from a spare room in my house in Annandale, and then ... in Suva, and then Auckland, I welcome the idea of adopting [this] as part of the Pacific [Media Centre] project ... I am very interested that this valuable 10-year archive be preserved and made accessible to journalists, students of media, and the general public' (Cronau, 2007). He also reaffirmed objectives of the project:

- PMW supports media and journalistic freedom by examining issues of ethics, accountability, censorship, media freedom and media ownership in the Pacific region.

- $\quad$ PMW publicly supports journalists facing challenges to their freedom of speech.

- $\quad$ PMW continues to be a lobbying tool for defending and expanding media freedom in the Pacific.

- $\quad$ PMW remains an independent, non-profit, non-government entity, and

- $\quad$ PMW remains accessible to journalists, editors, researchers, lawyers and other media workers supporting media freedom.

Cronau made a plea for the PMC to continue to service the PMW list-serve (then distributed by the non-profit APC server), in addition to the PMW web- 
site. The list-serve has continued for about 350 subscribers, mostly journalists, NGO advocates, civil servants, librarians, media services and student journalists. After an initial website development on D-Space hosted on the university's Kauri server for three years, PMW was 'reinvented' on a new Web 2 Pacific Media Centre website with a $\$ 15,000$ grant from the Pacific Development and Conservation Trust of New Zealand's Ministry of Internal Affairs awarded in late 2009. In a mid-term project report to the trustees in October 2010, PMW stated:

The development of this project comes at a critical time in the South Pacific. The abrogation of the 1997 Constitution in Fiji by the militarybacked regime and the passing of a controversial Media Industry Development Decree and serious pressure on the news media and civil society agencies in many Pacific countries underscores the need for an independent repository of information, analysis and research on the region's news media and creative industries. In spite of some technical hitches (the project has been developed on a new generation Web2 software Drupal after several disadvantages became apparent with the original DSpace software), the database has developed a remarkable range of content and information and will enhance the Pacific communities' right to know under Article 19 of the Declaration of Human Rights. By the time the project [cycle] is completed by mid-2011, it is bound to be widely recognised as a regional asset.

In addition, the $P M W$ project has reported on major regional issues such as the 2009 Samoan tsunami disaster one year on and these reports are already available in the public domain on our sister website Pacific Scoop www.pacific.scoop.co.nz (one example here: pacific.scoop. co.nz/2010/10/samoa-tsunami-report-outlines-damage-aid-effortsbut-silent-on-funding/ (Pacific Development and Conservation Trust Mid-Term Project Report, 2010)

Following the completion of the trust funding cycle, AUT's School of Communication Studies continued to fund the project for the next three years with Pacific Media Watch continuing to make a regional impact. In October 2011, PMW published the Pacific region's first media freedom report (Craddock, 2013; Perrottet \& Robie, 2011).

\section{The internship editors}

Since the establishment of the Pacific Media Centre at AUT University in 
October 2007, the Pacific Media Watch project was redeveloped with greater emphasis on educational, investigative and media freedom outcomes with postgraduate students taking on the role as a 'contributing editor' intern. All six interns since this development took place have been from the School of Communication Studies postgraduate programmes but from different countries-Australia, Kiribati, New Zealand, Norway, South Africa and Tonga - and several have graduated to important media positions and acknowledge that the PMW experience has helped them progress. The first intern, Taberannang Korauaba, established a new DSpace database of PMW files. In 2012, he gained first class honours for a masters degree on climate change and reporting and the media in Kiribati and was awarded a ViceChancellor's scholarship for a doctorate. Today he is the editor and publisher of both print and online editions of the Auckland-based Kiribati Independent and clashed with state authorities during 2012 over his investigative journalism work with an attempt to block his newspaper from publishing through a licensing bureaucracy ('Kiribati Independent newspaper shut', 22 June 2012; 'State silence over blocked newspaper', 18 January 2013; 'Independent newspaper publishing again', 25 January 2013). He was supported by PMW and the Paris-based Reporters Sans Frontières organisation, which wrote an interventionist letter in his support to the Kiribati government ('Newspaper still awaiting publication', 19 June 2012).

After her stint with PMW, Josephine Latu-Sanft also gained a first-class honours award for a masters degree and later edited the English-language Tongan Chronicle in Nuku'alofa. She was a media adviser with the Tongan government before being appointed to Brussels as press attaché for the African, Caribbean and Pacific (ACP) Group of States. Gladys Hartson, who followed Latu-Sanft for several months, later graduated and joined Spasifik magazine. Alex Perrottet, an Australian journalist who has worked with various aid projects in the Pacific, particularly Fiji and Samoa, was awarded two highly commended prizes for media innovation and investigative journalism in the annual Ossie Awards for best student journalism in Australia. He began a regular 'South Pacific Report' show on The Wire at Radio 95bFM in 2012 and is now working as an Asia-Pacific journalist in the Auckland bureau of Radio New Zealand International.

During 2013, the contributing editor was Daniel Drageset, who worked as a journalist for the public broadcaster Radio Norge in Oslo, Norway, for 
four years before embarking on a masters degree at AUT. He developed the PMW radio portfolio and is continuing the Pacific broadcasts. The current contributing editor, Anna Majavu, worked for the newspaper Sowetan in South Africa, which began as a liberation struggle publication in 1981, and is a trade unionist as well as researching for a master of philosophy.

Taberannang Korauaba recalls his early days as an intern at PMW when the pioneering monitoring service was no more than a corner desk in the Creative Industries Research Institute (CIRI) office at AUT when he first began work in 2007: 'Reading about attacks on the media and journalists and on new laws on media control or laws changed in an attempt to silence journalists, I thought, 'Why?' (Korauaba, emailed interview with author, 4 June 2013). He realised later what 'groundbreaking' work he was doing in establishing the initial database at AUT:

I couldn't believe then that what I was doing was for the future work of PMW. Part of my study [at the time] was to prepare an [honours] dissertation on media freedom in Kiribati, so reading through the media freedom stories was really helpful ...

I see the role of PMW is to connect government and journalists through this specialised area in regional media freedom, education and awareness. PMW is not associated with media owners, journalists or government—so that's the difference.

Josephine Latu-Sanft followed in 2009 at PMW and her Tongan-specific cultural and media experience meant that, along with a crisp analytical mind, she was able to develop some excellent reporting with an investigative edge on Tonga. Some of the reports that stood out during her tenure of the PMW role were her analysis of media freedom in the kingdom, a series of reports on the Princess Ashika tragedy — when 74 people perished in the sinking of an overloaded ferry on 5 August 2009 (Latu, 2010a) - and stories about repression in West Papua filed from the Pacific Islands Forum in Vanuatu (Latu, 2010b).

For PMW, I was reading every Pacific news website (including most national news sites) every day scouring the news for any media developments. For this reason, I think that while I was at PMC I was the most up-to-date and informed ever in my life about political and media developments in neighbouring Pacific countries. Managing a digital 


\section{INVESTIGATIVE JOURNALISM TRENDS}

archive of information on Pacific media was also an eye-opener because I went further to look for historical documents and academic papers written on Pacific media, and found a few gems - for instance, court records of key trials in Tonga involving media. (Latu-Sanft, interview with author, 9 June 2013)

For Alex Perrottet, his 'love of the Pacific' was the original motive that drew him to the Pacific Media Centre and working as the PMW intern in late 2010: 'My father worked in the Pacific and I grew up with lots of Pacific bowls, knives and spears around the house' (Perrottet, emailed interview with the author, 3 June 2013). When he enrolled at AUT to do his masters degree and joined the Asia-Pacific Journalism module, he 'naturally gravitated' to the PMC and the PMW contributing editorship.

The Pacific Media Centre is a hub of information and resources, as well as media experience, and it was primarily a learning experience, especially at the start ... The challenge was to be able to apply the skills I was immediately learning in the journalism education I was receiving in a Pacific setting (Ibid.)

Having been published online at Pacific Media Watch (on the PMC Online site) as well as Pacific Scoop (Robie, 2012), Perrottet realised how invaluable this was for a journalism student. When starting out on a new career, Perrottet, who was already a qualified lawyer, recognised a journalist needs 'more and more publication and name-recognition'. These outlets were the 'springboard for my early writing' and he believes the journalism school should make more use of them to project postgraduate students into their work.

I have learned countless skills that can't really be calculated. The experience and the contacts I made while working in this role were indispensable for my current position as reporter for Radio New Zealand International. [RNZI] values my experience at the Pacific Media Centre, having both studied and worked under Professor David Robie. Moreover, the research and publication experience was an essential aspect to my current credentials, and is regarded highly in the field of media.

Perrottet realised that the Pacific Media Centre was highly regarded in the wider community: 'Within three months of being appointed to the role, I was 
contacted by Radio New Zealand's Mediawatch programme to comment on a media storm around Campbell Live's reporting on the Samoan government's alleged mishandling of tsunami [aid] funds' (Wilson, 2010). He says editors regard PMW is important as a 'one-stop shop' for Pacific media information.

PMW is accessible ... to anyone in the world. It was originally designed as a simple news service to bring together any reports that look at the media, or have a specific media angle. Much of the time the reports are written from the Pacific and are aggregated as part of our service, with due recognition of the source through Creative Commons.

Other times, the media issue may be picked up by the editor and an original article produced and published on our site, again with references to the original source. Thus the wider community has a conglomeration of articles and references to anything remotely about the media in the Pacific.

The most 'striking experience' for Perrottet has been the opportunity of meeting a wide range of people and coordinating the reporting of different events: 'In the $2 \frac{1}{2}$ years in the role I have had the experience of interviewing the global head of Amnesty International; interviewing the most acclaimed Pacific media personalities in New Zealand and the Pacific; asking hard questions of the prime ministers of Australia and New Zealand as well as US State Department representatives at the 42nd Pacific Islands Forum in Auckland; interviewing a close friend of the King of Tonga; and having my award-winning work published online' (Perrottet, interview, 2013). Another stand-out experience was coordinating a reporting team of 10 students covering the Forum and the visiting United Nations secretary-general:

I learned the skills of editing and chief reporting with tight deadlines, and witnessed the power of the media as one [Papua New Guinean] reporter put a question to the United Nations Secretary-General about West Papua that sent [PMW] headlines around the world. (Perrottet, citing a report by Yamo, 2011)

When Norwegian radio journalist Daniel Drageset took on the PMW role in March 2013, he was uncertain about the challenge of monitoring the Pacific region, given that he was from Europe and relatively inexperienced compared with a local person - 'I am always a bit concerned that at any time 
I might miss stories' (Drageset, email interview with the author, 30 May 2013). But having completed the Asia-Pacific Journalism paper the year before, this introduced him to some of the issues of the region.

[This] paper boosted my interest in the Pacific, and when I was presented with the opportunity to continue learning about the region by taking on the role as contributing editor of PMW, I was sure it would be a good experience. Most importantly, I have learned a lot about the region. This includes political, social and cultural aspects of several countries. I have also learned skills of a more practical manner, such as web publishing and using Photoshop. (Ibid.)

Also as a non-native English speaker and writer, Drageset has advanced his English journalism writing skills. He has also used video publishing software to enhance his audio and investigative reports for packages on the PMC YouTube channel. Drageset (interview, 2013) endorses the emphasis on media freedom issues while also including 'lighter' content in PMW reports.

The current media development in all the Western world, and particularly in New Zealand, suggests that journalism is becoming commercialised, which leads to a particular kind of journalism that is more focused on entertainment and human interest stories, and less focused on issues of national and international importance. Because PMW emanates from a non-commercial institution, we have the opportunity to be more objective than other media and focus solely on issues of importance - rather than bowing down to commercial imperatives.

Drageset believes that one of the benefits of PMW to news media is that 'we are an objective and reliable source of information' that other media can follow-up. One of the tasks facing him is to research a range of sources and synthesise this into one comprehensive overview of the issue. 'This can be challenging,' he admits. Some national media in the Pacific only focus on the latest development and do not background the story. Research with an investigative edge is needed to put the development into perspective.

A further benefit for society ... is that we are one of the few remaining non-commercial news providers that upholds liberal ideals, such as freedom of expression and being a watchdog. Although these are big words, I do sincerely think that we are providing an important service, 
which in my and many media scholars' views, many representatives of the New Zealand media no longer are.

Lastly, the education community may take advantage of our database, which includes more than 8300 items spanning [17] years. (Drageset, interview, 2013)

In Drageset's view, PMW is 'truly unique - no other media outlets or NGOs do what we do'.

\section{Pacific Media Watch case studies}

Pacific Media Watch coverage features a striking blend of social media and citizen journalism 'breaks' - such as the Japanese tsunami in 2011 and its impact on the Pacific Island states; coup renegade Lieutenant-Colonel Ratu Tevita Mara's 'escape' from Fiji to Tonga (also in 2011); and the brutal torture of recaptured prisoners by Fiji security forces in 2013 - and dedicated inquiries and investigations by postgraduate student journalists and analysis by media commentators. Alex Perrottet singles out an opportunity to visit Samoa in September 2010 to carry out an investigative report marking the one-year anniversary of the tsunami that devastated part of the country, and also American Samoa and Tonga, as his most momentous experience (Samoan tsunami, 2011):

To be faced with that so early in my journalism career was a huge honour and privilege, particularly the visit to [survivor] Tai Apelu, who lost 14 members of her family while trying to save her hotel guests. As I interviewed her, the final tiles were being laid on a large mass-grave for the 14 deceased. It was an experience that I'll never forget. (Perrottet, interview, 2013)

Daniel Drageset highlights a 'viral' social media story about the torture of Fijian prisoners in March 2013, which he contributed to exposing. Another story that was a highlight featured Danish MP Marie Krarup, who made insulting comments in a blog about Māori cultural protocols while she visited Devonport Naval Base, Auckland, in March (Drageset, 2013e).

I was able to track down Krarup's original blog entry in Danish, and due to my Scandinavian language skills translate the entry into English. We were thus the first media outlet to go beyond Krarup's derogatory 
comments [and highlight her main criticism of] New Zealand inability to defend itself militarily because of multicultural developments ... We managed to be more analytical than any other media ... In the followup story, I made use of AUT University's relationship with the Danish School of Journalism to interview professor Hans-Henrik Holm for his reaction (Drageset, email interview with the author, 29 May 2013).

Pacific Media Watch has gained a reputation of taking on 'underdog' cases of media freedom, especially those involving Indigenous and cultural rights. Some of the issues that have figured strongly in its case histories over several years have included Rapanui independence from Chile (McCall, 2010) and West Papuan 'black spot' human rights violations and the safety of journalists (Perrottet \& Robie, 2011b; Robie, 2013). But the PMW history began with the celebrated case of the 'Tongan three'.

\section{The case of the 'Tongan three'}

20 September 1996

'Akilisi Pohiva was jailed for contempt of Parliament on 20 September 1996 after having leaked an impeachment notice against Justice Minister Tevita Tupou. Kalafi Moala and Filokalafi 'Akau'ola were jailed for publishing the leaked document in a front-page story in the Taimi 'o Tonga. In its later ruling, the Tongan Supreme Court found that constitutional provisions such as Clause 10 for trials and sentencing under law, and Clause 11 providing for indictments, defence procedures and the right to call witnesses were breached. It also ruled that the three men had not been correctly found guilty by the Legislative Assembly of the offence they were accused of under Clause 70 of the constitution. The Tongan government defended its parliamentary action, saying the journalists broke the law and should be accountable (see Robie, 1996, p. 12).

The 'Tongan three' furore erupted after the outspoken weekly newspaper Taimi 'o Tonga (Tongan Times) published a Tongan-language story on September 4 under the headline 'PARLIAMENT IMPEACHES MINISTER FOR JUSTICE' about an untabled impeachment notice alleging abuse of office against Justice Minister Tupou.

As the Tongan government had tried in the past to silence Pohiva and journalists who had tried to shed light on the maladministration of cabinet 
and Parliament, it moved quickly to stifle dissent over the jailings by suspending the Legislative Assembly on October 4 until the middle of 1997. King Taufa'ahau Tupou IV used his powers as absolute monarch to close the House after it had voted to impeach Justice Minister Tupou. At the time the 30-member Legislative Assembly was dominated by 21 unelected representatives of the kingdom's noble families (cabinet ministers were appointed by the King) plus nine elected people's representatives.

Shocked Tongans interpreted the closing of Parliament as a way for the monarch to 'buy time' for the nobles to regroup as the House faces growing democratic demands. Kalafi Moala challenged Parliament over the 'historical trial', claiming the three had been given a prejudiced hearing. In an article in the Taimi 'o Tonga headlined 'WE DIDN'T GET A FAIR TRIAL', Moala (1996) defended his paper's action in publishing an untabled motion seeking the impeachment of Justice Minister Tupou for allegedly going to the Atlanta Olympics and being paid full parliamentary allowances (Robie, 1996, p. 14).

Amnesty International declared the three prisoners of conscience-a term the organisation uses to describe people who are in any form of detention because of their political, religious or other conscientiously held beliefsprovided that they have not used or advocated violence. Amnesty wrote to the king, saying it believed the three men had been imprisoned as a result of their peaceful exercise of the right to freedom of expression, guaranteed by Article 19 of the Universal Declaration of Human Rights and protected by Article 19 of the International Covenant on Civil and Political Rights.

The organisation noted that Clause 7 of the Tongan Constitution of 1875 stated:

It shall be lawful for all people to speak write and print their own opinions and no law shall ever be enacted to restrict this liberty. There shall be freedom of speech and of the press for ever but nothing in this clause shall be held to outweigh the law of slander or the laws for the protection of the King and the royal family.

The Tongan government reacted bitterly over the flood of international criticism about the jailings, claiming that the men had set themselves up to be 'martyrs' and accusing press freedom and other organisations of waging a campaign of 'media terrorism' against the kingdom (Robie, 1996, p. 16). Acting Chief Secretary 'Eseta Fusitu'a acknowledged Agence France-Presse news agency, Radio Australia and Radio New Zealand for contacting the 
government to seek information, but condemned a 'blacklist' of protesting media organisations, including Pacific Media Watch (PNG), World Press Freedom Committee (USA), Australian Centre for Independent Journalism (Sydney), Pacific Journalism Review (PNG), National Press Club (PNG), Pacific Star Pty Ltd (publishers of The National, PNG), International Press Institute (Austria), Word Publishing Co Ltd (PNG), NZ Journalists Training Organisation (NZ), NZ Engineering Printing and Manufacturing Union, Amnesty International (UK), the New Zealand Herald and many other print and radio media.

\section{Fiji coup censorship of Wansolwara}

\section{May 2000}

In Fiji, Wansolwara of the University of the South Pacific has arguably been the most successful model for a training newspaper in the Oceania region because it has been able to self-fund publication for more than 17 years and consolidate its publishing structure. The newspaper has also published concurrently with its sister publication Pacific Journalism Online, which later became Wansolwara Online and has won a string of awards (Pearson, 2001; Robie 2004). The newspaper has provided strong coverage of environmental issues, development strategies, human rights and social justice, but coverage of the George Speight attempted coup in has been one of the highlights of the newspaper's history. Within days of the Speight coup on 19 May 2000, the students' website and newspaper had created its own international niche market (Robie, 2010). In a sense, this was an 'internet coup', and the students were a vital part of it. And the plaudits were fullsome: 'Young and brave,' said the IPI Global Journalist. 'In a Pacific island paradise, journalism students cover a strange coup attempt for course credits' (Ransom, 2000). 'From trainees to professionals. And all it took was a coup,' said the Commonwealth Press Union News (Gounder, August, p. 7). 'Some of the best reporting has come from USP's journalism program ... it was a goldmine of information until it was shut down by the university ... "for security reasons",' wrote New Zealand's City Voice (Rose, 2000). Although the USP programme was ill-equipped logistically for such sustained daily reportage, it at least had a well-established, two-year-old website in the formative days of online media, Pacific Journalism Online, and Wansolwara newspaper already in place. It also normally had access to a student FM radio station 
on campus, Radio Pasifik, but university authorities closed this immediately after the coup.

On Sunday, May 29, hours after a mob supporting coup leader George Speight attacked Fiji Television and cut transmission for almost 48 hours, and the military declared martial law. The university authorities closed the USP journalism website without explanation, fearing a similar raid on the sprawling Laucala campus (Cass, 2002). Undaunted, the students were offered an alternative site hosted by the Department of Social Communication and Journalism at the University of Technology, Sydney, and carried on publishing from the next day. ACIJ director Associate Professor Chris Nash at UTS said:

The suggestion that journalism staff and students, and indeed any academics, might somehow desist from reporting, commenting and publishing on the current situation is akin to suggesting that doctors and nurses should turn their backs on wounded people in a conflict. It's unconscionable. (Nash, 2000)

Pacific Media Watch took a leading role in reporting this attempt of censorship of the journalism website and also the newspaper Wansolwara with global protests coming from Reporters Sans Frontières in Paris, the Commonwealth Journalists' Association, the New York-based Committee to Protect Journalists and others (Robie, 2010, p. 111). Eventually, the journalism programme was allowed to re-establish its website on June 28 and resume normal publication of the newspaper, and the student team won four awards at the 2000 Ossie Awards rewarding the best of student journalism in Australasia.

\section{3: Tōhoku earthquake and tsunami, Japan}

\section{March 2011}

Pacific Scoop, a joint project between the Pacific Media Centre and independent Scoop Media Limited, cut is teeth as a news website four weeks after being launched with a tsunami in Samoa on 29 September 2009 when 189 people were killed, especially children. Student journalists along with reporters in Samoa provided compelling coverage and on the anniversary one year later Pacific Media Watch editor Alex Perrottet travelled to Samoa and wrote a series of four major reports about the reconstruction process. Less than three weeks after the Christchurch earthquake on February 22 and the loss of 
181 lives (the second-deadliest natural disaster since the 1931 Napier earthquake), a massive earthquake and tsunami struck the north-east Pacific coast of Japan, off Tohuku. It was the most powerful known earthquake to have hit Japan and one of the five strongest in the world since modern record-keeping began in 1900. The Japanese Prime Minister Naota Kan described it as 'the toughest and most difficult crisis for Japan in the 65 years since the Second World War' ('Anxiety in Japan grows', 14 March 2011). The Japanese National Police agency confirmed 15,389 deaths and 3642 people missing with 125,000 buildings damaged or destroyed. Besides the catastrophic loss of life, there were several nuclear accidents, including level seven meltdowns at three reactors in the Fukushima nuclear power plant.

The devastating earthquake and tsunami struck on a Friday evening peak hour viewing and three of the four main free-to-air TV channels ran breaking news coverage. Pacific Scoop and Pacific Media Watch also went into 'Breaking News mode' carrying several stories on that first evening, mostly stories written by the PMW editor who phoned contacts in Japan to get a Pacific perspective, including a Filipino coach of a junior New Zealand rugby team visiting Tokyo. Over later days, PMW covered various regional angles on the post-tsunami destruction. While most international news media was reporting 'no problems' for the Pacific, PMW ran several stories showing where there had been considerable damage and harm, notably in parts of Hawai'i such as the Big Island. It also reported on the trauma and the steps being taken towards recovery.

\section{4: Mara's 'great escape' affair}

\section{May 2011}

On Saturday, 14 May 2011, a previously unknown group, TruthforFiji, suddenly posted a video on YouTube which featured one of the 2006 military coup leaders in Fiji making a impassioned plea for regime change ("Accused Fiji colonel slams "hateful dictatorship", PMW, 14 May 2011). Facing charges for sedition along with a high-ranking colleague, who had also been charged with plotting a counter-coup, Lieutenant-Colonel Ratu Tevita Kapaiwai Lutunauga Uluilakeba Mara defected in very controversial circumstances. He fled Fiji while facing his charges in open court, not a court martial, and escaped to Tonga with the help of the Tongan Navy. He subsequently became the international pin-up boy for opposition to the Bainimarama coup. Pacific 
Media Watch broke this story by diligently following up the YouTube video and running a story based around Mara's recorded comments. By Monday, two days later, it was front pages news in Australia, New Zealand and the Pacific and threatened to spill over into a fullscale military confrontation between Fiji and Tonga.

Ratu Ului is the youngest son of the late President and founding prime minister, Ratu Sir Kamisese Mara, who was ousted by the George Speight attempted coup in 2000. In 2001, Colonel Mara was named Army Chief-of-Staff succeeding Colonel Meli Saubulinayau, a close relative of his. This position is the fourth highest in the Fijian military, behind that of the Commander, Commodore Frank Bainimarama, Deputy Commander and Chief-of-Staff RFMF Brigadier-General Mohamed Aziz and the Land Force Commander, Brigadier-General Pita Driti.

In December 2006, the Fiji Military Forces took control of Fiji in a bloodless coup. The army claimed it would remove corruption and corrupt politicians and return to barracks within a year. Lieutenant-Colonel Mara was in charge of the 3 Fiji Infantry Regiment on that day and for the next four years. He has also been accused of human rights violations in the early coup period, an accusation he denies.

What was remarkable about the Mara escape from Fiji, where he was granted a Tongan passport because of his family ties with the monarchy in Nuku'alofa, was how both Australia and New Zealand lifted the ban on coup perpetrators on visiting both countries to lobby for support. After breaking the story and being fast with new revelations as Mara minders drip-fed further videos on YouTube, Pacific Media Watch and Pacific Scoop continued to break developments. Student journalists monitored the Mara travelling road show and attended political meetings and wrote critical accounts.

At a public meeting in the South Auckland suburb of Papatoetoe, student editor Alex Perrottet of PMW interviewed Ratu Ului and profiled his planned global campaign

\section{Fiji security forces torture prisoners}

\section{March 2013}

In Pacific Media Watch editor Daniel Drageset's first week on the job, he went through a baptism of fire in investigating allegations of torture by Fijian security forces. This was another example of citizen media when a 
nine minute clip allegedly showing out-ofuniform security officers systematically beating and torturing two handcuffed prisoners surfaced initially on social media. Drageset first needed to cross-check the authenticity and the identity of security officers portrayed in this video. Were they police or military officers, as initially alleged? His job was made slightly easier when the state-run broadcaster Fiji Broadcasting Corpora-

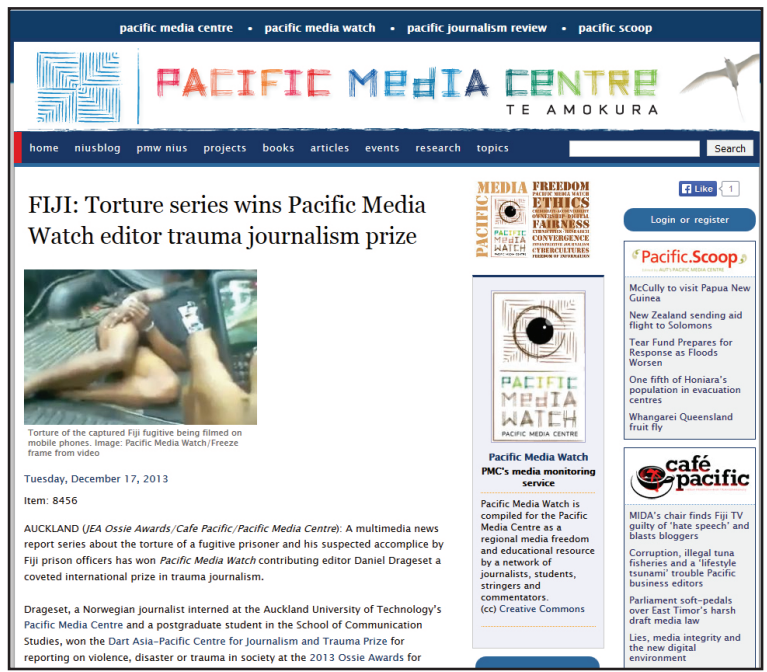

Figure 1: A Pacific Media Watch Fiji torture and social media investigation series won the Dart AsiaPacific Centre trauma journalism prize in 2013. tion ran a news item about it (but not the video). After further checks, PMW published the first international news item about the torture with an embedded video widget. At least five stories followed on the PMW and Pacific Scoop websites. As Drageset recalled later: 'The first three stories I did for PMW were about the abuse of escaped prisoners, who were filmed [by mobile phones]. The video was uploaded to YouTube and went viral in Fiji. It seemed like many other media copied what we did' (Drageset, 2013a, 2013b, 2013c). In his first story, Drageset reported:

Fiji police are investigating an online video showing two men in handcuffs being brutally abused by other men, suspected by critics of being state officials in plain clothes.

In the nine minute video posted on YouTube yesterday, a man is shown being beaten by wooden and metal poles while lying helpless on the back of a pick-up truck.

Unable to avert any attacks, the man is stripped of his shorts and underwear, pushed and pelted with items. At the end of the video the man has several visible bruises on his thighs.

Anti-regime website Coupfourpointfive claimed the video was evidence of Fiji police brutality against prisoners - but the video does 
not show any of the assailants clearly, so it is not clear who took part in the act.

In the video, another man is shown being dragged by a dog in the grass and assaulted while several others are watching.

Some scenes show the assailants laughing and filming the assault on cellphones. (Drageset, 2013a)

Later reports indicated that Fiji authorities had confirmed that 'security' officers had carried out the torture but declined to conduct an independent inquiry. Amnesty International and other human rights groups protested. One of the handcuffed men beaten was identified as 24-year-old escaped prisoner Iowane Benedito, whose shocked mother declared: 'I knelt down and cried, asking the Lord to give me peace.' (Drageset, 2013d). Three months later, there were still no prosecutions and Radio Australia's Pacific Beat programme quoted a highly experienced Melbourne detective as saying that the Fiji police should have identified the assailants from the video ('Fiji torture investigation too slow: ex-detective', 30 May 2013). This series of articles subsequently won Drageset the Dart Asia-Pacific Centre for Journalism and Trauma Prize for reporting on violence, disaster or trauma at the 2013 Ossie Awards for student journalism in Australia. Judge Cait McMahon, director of the Melbourne-based centre, described Drageset's work as an 'impressive investigation into alleged police torture'. ('Fiji torture series wins Pacific Media Centre student trauma prize', 17 December 2013).

\section{Conclusion}

Four leading global media freedom organisations provide annual reports assessing the state of press freedom. Three of these organisations produces a report that reflects its stated mission through the prism of individual journalists-New York-based Committee to Protect Journalists promotes 'freedom of the press throughout the world by defending the right of journalists to report news without fear of reprisal'; Paris-based Reporters Sans Frontières 'defends imprisoned journalists and press freedom throughout the world'; and the Vienna-based International Press Institute is 'dedicated to the protection of press freedom and the improvement of the practices of journalism'. All play an advocacy role supporting the plight of journalists and lobbying governments to remedy violations of journalists' rights (Becker, 2003, p. 107). 
At the other end of the scale, while the small Pacific Media Watch project has some affiliation with RSF, its independent role is modest and focused on a simpler objective in Oceania-it 'supports media and journalistic freedom by examining issues of ethics, accountability, censorship, media freedom and media ownership in the Pacific region' and 'supports journalists facing challenges to their freedom of speech' (Pacific Media Watch Project, 2007). PMW has an 'agenda-setting' focus, but rarely indulges in lobbying, preferring to focus on the independence and credibility of its journalism to have a wider impact. The genesis of PMW in 1996 was the jailing of Tongan newspaper publisher and broadcaster Kalafi Moala and his two colleagues. Since then, PMW has often been the first to break similar media freedom stories, such as when Vanuatu Daily Post publisher Marc Neil-Jones was brutally assaulted in 2011 by a government minister and his henchmen (Neil-Jones, 2011).

Apart from being a unique resource for the region's news media and nongovernment organisations as an important starting point for covering regional media freedom issues, PMW provides support to the region's journalists and an influential role in providing authentic and reliable articles. Many of the region's newspapers, news agencies and news services republish stories from the PMW service. They include the Cook Islands News, Fiji Sun, Pacific Islands Report, PACMAS, Pacnews, PasiMA, Samoa Observer, The Fiji Times, and Vanuatu Daily Post.

As a critical news evaluator, PMW has been reporting protest stories that other New Zealand, even international, media are not covering, or are only covering superficially. This means greater diversity and more analysis of the region's media. 'An added benefit for PMW is that is situated in New Zealand,' observes former editor Alex Perrottet (interview, 2013), 'which is at a healthy distance from the Pacific Islands and close enough to follow events accurately. Having a more open media climate [in New Zealand] enables us to report freely on incidents and [developments] without the threats and constraints.'

Pacific Media Watch: www.pacmediawatch.aut.ac.nz

\section{Interviews}

Drageset, D. (2013, May 30). Emailed interview with the author. Korauaba, T. (2013, June 4). Emailed interview with the author. Latu-Sanft, J. (2013, June 9). Emailed interview with the author. Perrottet, A. (2013, June 3). Emailed interview with the author. 


\section{References}

Accused Fiji colonel slams 'hateful dictatorship' in YouTube plea (2011, May 14). Pacific Media Watch/Pacific Scoop. Retrieved on June 5, 2013, from www.pmc.aut. ac.nz/articles/video-accused-fiji-colonel-slams-hateful-dictatorship-youtube-plea

Anxiety in Japan grows as death toll steadily climbs (2011, March 14). CNN Newswire [Video]. Retrieved on 25 November 2011, from http://edition.cnn.com/2011/ WORLD/asiapcf/03/13/japan.quake/index.html?iref=NS1

Cass, P. (2002). Baptism of fire: How journalism students from the University of the South Pacific covered the Speight putsch and its aftermath. The Round Table: The Commonwealth Journal of International Affairs, 91(366), 559-574.

Craddock, P. (2013). Pacific journalists and frontline freedom [Review]. Pacific Journalism Review, 19(1), 299-302.

Cronau, P. (2005). Supporting letter for the Pacific Media Watch project. 19 October 2005.

Drageset, D. (2013a, March 5). Fiji investigation into alleged police brutality. Pacific Media Watch 8214. Retrieved on June 5, 2013, from www.pmc.aut.ac.nz/pacificmedia-watch/fiji-investigation-alleged-police-brutality-8214

Drageset, D. (2013b, March 6). Viral 'horror' torture video prompts Fiji Times editorial. Pacific Media Watch 8215. Retrieved on June 5, 2013, from www.pmc. aut.ac.nz/pacific-media-watch/fiji-viral-horror-torture-video-prompts-fiji-timeseditorial-8215

Drageset, D. (2013c, March 6). Corrections officers responsible for beating, claims anti-regime blog. Pacific Media Watch 8216. Retrieved on June 5, 2013, from www.pmc.aut.ac.nz/pacific-media-watch/fiji-corrections-officers-responsiblebeating-claims-anti-regime-blog-8216

Drageset, D. (2013d, March 8). Police confirm 'security personnel' responsible for brutal beating. Pacific Media Watch 8218. Retrieved on June 5, 2013, from www.pmc.aut.ac.nz/pacific-media-watch/fiji-police-confirm-security-personnelresponsible-brutal-beating- 8218

Drageset, D. (2013e, April 8). Danish MP apologises after calling Māori powhiri grotesque, mocking 'free-ride' defence. Pacific Media Watch 8248. Retrieved on June 5, 2013, from www.pmc.aut.ac.nz/pacific-media-watch/nz-danish-mpapologises-after-calling-powhiri-grotesque-and-less-civilised-8248

Fiji torture investigation too slow: ex-detective (2013, May 30). ABC Radio Australia Pacific Beat. Retrieved on June 7, 2013, from www.radioaustralia.net.au/ pacific/2013-05-30/fiji-torture-investigation-too-slow-exdetective/1138710

Fiji torture series wins Pacific Media Centre student editor trauma prize (2013, December 17). Pacific Media Centre Online. Retrieved on January 19, 2014, from www.pmc.aut.ac.nz/pmc-blog/fiji-torture-series-wins-pacific-media-watchstudent-editor-trauma-prize

Gounder, C. (2000, August). Taking a coup in your stride. CPU News. London: Commonwealth Press Union, $\mathrm{p} 7$.

Ingham, L. (2007). Australian shield law for journalists: A comparison with New 


\section{INVESTIGATIVE JOURNALISM TRENDS}

Zealand, the United Kingdom and the United States. [Unpublished report]. Canberra: Australian National University and Special Broadcasting Service (SBS).

Independent newspaper publishing again (2013, January 25). Pacific Media Watch 8180. Retrieved on June 4, 2013, from www.pmc.aut.ac.nz/pacific-media-watch/ kiribati-independent-newspaper-publishing-again-8180

Kiribati Independent newspaper shut down indefinitely (2012, June 22). Pacific Media Watch 7993. Retrieved on June 4, 2013, from www.pmc.aut.ac.nz/pacific-mediawatch/kiribati-kiribati-independent-newspaper-shut-down-indefinitely-7993

Latu, J. (2010a, April 1). Damning Ashika inquiry report blames 'failure of authority' for disaster. Pacific Scoop. Retrieved on June 4, 2013, from www.pmc. aut.ac.nz/articles/damning-ashika-inquiry-report-blames-\%E2\%80\%98failureauthority $\%$ E2\%80\%99-disaster

Latu, J. (2010b, August 7). Vanuatu stands alone on West Papua human rights violations. Pacific Media Centre Online. Retrieved on June 4, 2013, from www.pmc. aut.ac.nz/articles/vanuatu-stands-alone-west-papua-human-rights-violations

McCall, G. (2010, December 15). Chilean ‘thuggery’ on Rapanui-some parliamentarian responses. Pacific Media Watch/Pacific Scoop. Retrieved on June 5, 2013, from www.pmc.aut.ac.nz/articles/chilean-thuggery-rapa-nui-some-parliamentarianresponses

Moala warns over 'new forces' in Pacific media freedom struggle (2010, Oct 6). Pacific Media Watch 7062. Retrieved on June 6, 2013, from www.pmc.aut.ac.nz/ pacific-media-watch/2010-10-06/region-moala-warns-over-new-forces-pacificmedia-freedom-struggle

Moala, K. (1996, Sept 25). 'We didn't get a fair trial' [Translation from Tongan by Lopeti Senituli]. Pacific Journalism Review, 3(2), 13-14. Retrieved on June 5, 2013, from www.pjreview.info/articles/we-didnt-get-fair-trial-666

Moala, K. (2002). Island kingdom strikes back: The story of an independent island newspaper - Taimi 'o Tonga. Auckland: Pacmedia Publishers.

Nash, C. (2000). Letter by the Australian Centre for Independent Journalism (ACIJ) director to the USP Vice-Chancellor, 13 June 2000.

Neil-Jones, M. (2011, May 9). Vanuatu publisher Neil-Jones tells of his struggle for a free press. Pacific Media Centre Online. Retrieved on June 5, 2013, from www. pmc.aut.ac.nz/articles/vanuatu-publisher-neil-jones-tells-his-struggle-free-press

Newspaper still awaiting publication licence after five months (2012, June 19). Reporters Sans Frontières [Plus letter to the Kiribati government]. Retrieved on June 4, 2013, from en.rsf.org/kiribati-newspaper-still-awaiting-19-06-2012,42814.html

Pacific Media Watch Project (2007). AUT University's School of Communication Studies. Retrieved on June 3, 2013, from www.aut.ac.nz/study-at-aut/study-areas/ communications/profile/media-networks/pacific-media-watch-project

Pacific Media Watch expands resources (2010). Community Matters, NZ Government. Retrieved on June 3, 2013, from www.communitymatters.govt.nz/Successstories---Trusts-and-Fellowships-success-stories---Pacific-Media-Watch-expandsresources 
Pacific Development and Conservation Trust Mid-Term Project Report PDEVCON 112-2009 (2010). Pacific Media Centre, AUT University. 22 October 2010.

Pearson, M. (2001). Ossies recognise promising talent of the future. PANPA Bulletin, February, 19.

Pearson, M. (2013, April 11). Call for uniform shield laws is worth supporting, but not an easy fix. Journlaw [blog]. Retrieved on June 4, 2013, from http://journlaw. com/2013/04/11/call-for-uniform-shield-laws-is-worth-supporting-but-not-aneasy-fix/

Perrottet, A. (2011, May 4). World Press Freedom Day and who's who in Pacific media groups. Pacific Media Watch 7427. Retrieved on June 3, 2013, from www. pmc.aut.ac.nz/pacific-media-watch/2011-05-04/region-world-press-freedom-dayand-whos-who-pacific-media-groups

Perrottet, A., and Robie, D. (2011a). Pacific press freedom 2011: A status report. Pacific Journalism Review, 17(2), pp. 148-186. Retrieved on June 3, 2013, from www.pjreview.info/articles/pacific-media-freedom-2011-status-report-513

Perrottet, A., and Robie, D. (2011b, October 24). Papua a media black spot, New Matilda. Retrieved on November 23, 2011, from http://newmatilda.com/2011/10/24/ papua-media-black-spot

Ransom, S. (2000). Young and brave: In Pacific island paradise, journalism students cover a strange coup attempt for course credit. IPI Global Journalist, Third Quarter, 6(3), 26-28.

Robie, D. (1991, April 10). Tongan passport row stirs unrest. GreenLeft Weekly, Issue 7. Retrieved on June 3, 2013, from www.greenleft.org.au/node/1633

Robie, D. (1996). The contempt case of the 'Tongan three'. Pacific Journalism Review, 3(2), 10-19.

Robie, D. (2004). Mekim Nius: South Pacific media, politics and education. Suva: University of the South Pacific Book Centre.

Robie, D. (2010). Pacific freedom of the press: Case studies in independent campusbased media models. Pacific Journalism Review, 16(2), 99-126.

Robie, D. (2012). Independent journalism in the South Pacific: Two campusbased media case studies in Fiji and New Zealand. Global Media Journal, 6(1). Retrieved on June 5, 2013, from www.commarts.uws.edu.au/gmjau/v6_2012_1/ david_robie_AA.html

Robie, D. (2013). Conflict reporting in the South Pacific: A critical reflexive approach to Timor-Leste and West Papua. Media Asia, 40(2), 147-161.

Rose, J. (2000, June 8). Fiji: The internet coup. City Voice (p. 8). Wellington: New Zealand.

Samoan tsunami recovery series wins Perrottet student media honour. (2011, March 8). Pacific Media Centre Online. Retrieved on May 27, 2011, from www.pmc. aut.ac.nz/pmc-blog/2011-03-08/samoan-tsunami-recovery-series-wins-perrottetstudent-media-honour

State silence over blocked newspaper-free edition circulated (2013, Jan 18). Pacific Media Watch 8176. Retrieved on June 4, 2013, from www.pmc.aut.ac.nz/ 


\section{INVESTIGATIVE JOURNALISM TRENDS}

pacific-media-watch/kiribati-state-silence-over-blocked-newspaper-free-editioncirculated-8176

Van Fossen, A. (2007). Citizenship for sale: passports of convenience from Pacific island tax havens. Commonwealth and Comparative Politics, 45(2), 138-163. Retrieved on June 3, 2013, from www98.griffith.edu.au/dspace/bitstream/handle/10072/18132/49480_1.pdf?sequence $=1$

Wilson, C. (2010, November 8). Tsunami aid disaster report now under fire in Mediawatch episode. Pacific Media Watch 7115. Retrieved on June 4, 2013, from www. pmc.aut.ac.nz/pacific-media-watch/2010-11-08/samoa-tsunami-aid-disaster-reportnow-under-fire-mediawatch-episode

Yamo, H. (2011. September 7). Human rights 'fundamental' in member countries and worldwide, says UN chief. Pacific Scoop/Pacific Media Watch. Retrieved on June 5, 2013, from http://pacific.scoop.co.nz/2011/09/human-rights-fundamentalin-member-countries-and-worldwide-says-un-chief/

Dr David Robie is director of the Pacific Media Centre and professor of journalism in AUT University's School of Communication Studies. He is also co-founding convenor of the Pacific Media Watch Project. An earlier version of this article was presented as a paper at the Protest Movements: Free Speech and the Media conference at the University of Westminster, London, on 12-13 June 2003. david.robie@aut.ac.nz 